\title{
Syndrome of Growth Resistance, Obesity, and Intellectual Impairment with Precocious Puberty
}

\author{
DUNCAN R. MACMILLAN, CHONG BIN KIM, and BERNARD WEISSKOPF \\ From the Section of Pediatric Endocrinology and the Child Evaluation Center, Department of Pediatrics, \\ University of Louisville School of Medicine, Louisville, Kentucky, U.S.A.
}

\begin{abstract}
MacMillan, D. R., Kim, C. B., and Weisskopf, B. (1972). Archives of Disease in Childhood, 47, 119. Syndrome of growth resistance, obesity, and intellectual impairment with precocious puberty. A syndrome of growth resistance, obesity, and intellectual impairment with precocious puberty is described. Two girls presenting with many of the manifestations of the Prader-Willi syndrome, including growth resistance, obesity, and intellectual impairment, also exhibited precocious sexual maturation. It is suggested that this syndrome represents a hypothalamic disturbance closely related to the Prader-Willi syndrome and should be considered one of its variants.
\end{abstract}

In 1956, Prader, Labhart, and Willi (1956) provided the original description of a syndrome characterized by short stature, obesity, mental retardation, hypogonadism, and hypotonia. Further basic definition of this syndrome was contributed by Prader and Willi (1963) and by Laurance (1961) and, to date, over 90 cases have been reported. Retarded skeletal maturation has been frequently observed and the onset of puberty delayed in the older children reported (Zellweger and Schneider, 1968; Hoefnagel, Costello, and Hatoum, 1967; Juul and Dupont, 1967; Laurance, 1967; Cohen and Gorlin, 1969; Dubowitz, 1967). In no instance has early sexual maturation or appreciably advanced bone age been described.

Two girls with severe obesity, short stature, and intellectual impairment, who, in addition, showed evidence of sexual precocity, were recently seen. Though this clinical picture may represent a separate syndrome, the similarity of these children, in other respects, to cases of the Prader-Willi syndrome suggests that sexual precocity may occasionally occur as another manifestation of disturbed hypothalamic function in the PraderWilli syndrome.

\section{Case Reports}

Case 1 (Fig. 1). This 5-year-old white girl was born to a 30-year-old mother after an uncomplicated term pregnancy and delivery. The infant weighed $2296 \mathrm{~g}$, but was soon noted to be lethargic and hypotonic, and did

Received 20 August 1971. not nurse well. She slept excessively and gained little weight during the first month. Thereafter, she gained rapidly, and at 4 months of age she had doubled her birthweight. At 6 months of age she was still lethargic and floppy, and the question of cretinism was raised. Thyroid therapy was started by her physician on the basis of clinical findings with some improvement in wakefulness. Her motor development was delayed; she sat at $8 \frac{1}{2}$ months, walked at 21 years, and spoke her first discernible word at 3 years of age. At 5 years of age she was referred, because of obesity, language difficulties, enuresis, and hyperphagia. Her weight was $46 \mathrm{~kg}$ (>95th centile); her height was $107 \mathrm{~cm}$ (45th centile). She showed generalized obesity, odd facies with right exotropia, retarded behaviour, and short tapering fingers with a simian line on the left palm. There was a mild generalized reduction in muscle power and tone; there were no other abnormalities. In particular, the fundi were normal, there were no other stigmata of Down's syndrome, no evidence of thyroid dysfunction, and the genitalia were considered normal for age at that time. Thyroid therapy was discontinued, and after six weeks, the ${ }^{131}$ I uptake was $24 \%$ at 24 hours, the thyroid appeared normal by scan, the serum cholesterol was $137 \mathrm{mg} / 100 \mathrm{ml}$, and the PBI was 3.5 $\mu \mathrm{g} / 100 \mathrm{ml}$.

Psychometry gave a full-scale IQ of 52. Chromosome karyotype was normal female.

At 6 years and 4 months of age (Table), pubic hair and breast enlargement were noted. At this time the child's height remained below the 50th centile though her weight continued its rapid increase. The ovaries were not palpably enlarged. Vaginal smear showed epithelial changes consistent with moderate oestrogen effect and 24-hour oestrogen excretion was $7 \mu \mathrm{g}$. 


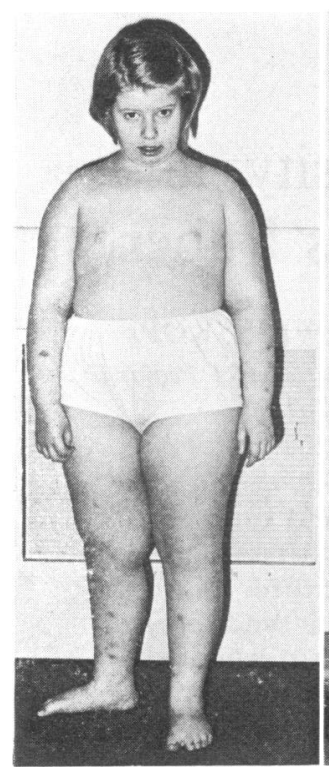

FIG. 1.-Case 1, aged $6 \frac{1}{2}$ years.

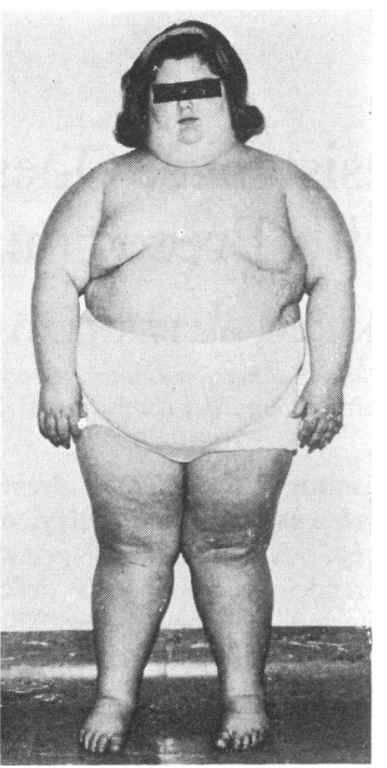

FIG. 2.-Case 2, aged $11 \frac{1}{2}$ years.

Other endocrine investigations are given in the Table. Skull $x$-ray was normal.

Progression of sexual and skeletal maturation has been slow in the four years since sexual development was first noted and menstruation has not occurred.

Case 2 (Fig. 2). This 11-year-old girl was referred for obesity and poor school performance. She was born after an uncomplicated gestation of 40 weeks to a 28-year-old mother. She weighed $3005 \mathrm{~g}$ at birth, was irritable, and not hypotonic in early infancy, fed well, and gained adequately. She sat at 6 months of age, walked at 14 months, and was toilet-trained at 2 years.

Obesity became a cause for concern around the age of 5 years. At 7 she was studied on the endocrine service of another university hospital. Physical examination at that time showed short stature, obesity, and the presence of long dark pubic hairs but was otherwise normal. Her bone age was advanced by one year and her urinary $17-\mathrm{KS}$ and $17-\mathrm{OHCS}$ were slightly raised but were suppressed readily with cortisone. Subsequently she continued to gain weight in spite of supposed adherence to a 500 calorie diet, and pubic hair increased slowly in amount. The time of appearance of pubertal breast development was uncertain due to the extreme obesity.

She was first seen by us at the age of 11 years and 5 months (Table). Her height was $129 \mathrm{~cm}$ ( $<5$ th centile), weight $57 \mathrm{~kg}$ ( $>95$ th centile), and blood pressure $110 / 65 \mathrm{~mm} \mathrm{Hg}$. She was a short, immature looking girl, with generalized obesity and without hirsutism or dark striae. There were no features to

TABLE

Endocrine Evaluation

\begin{tabular}{|c|c|c|}
\hline & Case 1 & Case 2 \\
\hline $\begin{array}{l}\text { Age of evaluation }(\mathrm{yr}) \\
\text { Weight age }(\mathrm{yr}) \\
\text { Height age }(\mathrm{yr}) \\
\text { Bone age }(\mathrm{yr}) \\
17-\mathrm{KS}(\mathrm{mg} / 24 \mathrm{hr}) \\
17-\mathrm{OHCS}(\mathrm{mg} / 24 \mathrm{hr}) \\
\text { Chromosomes } \\
\text { Vaginal cornification } \\
\text { Urinary oestrogen }(\mu \mathrm{g} / 24 \mathrm{hr}) \\
\text { Urinary gonadotropin } \\
\text { Growth hormone response } \\
\text { (m } \mathrm{mg} / \mathrm{ml}) \\
\text { 17-OHCS-metyrapone test } \\
(\mathrm{mg} / 24 \mathrm{hr})\end{array}$ & $\begin{array}{c}64 / 12 \\
10 \frac{1}{2} \\
6 \\
11 \\
2 \cdot 1 \\
3 \cdot 7 \\
\text { Normal XX } \\
\text { Moderate } \\
7 \\
\text { None detected } \\
0 \cdot 7 \rightarrow 1 \cdot 1 \\
\\
3 \cdot 7 \rightarrow 19 \cdot 0\end{array}$ & $\begin{array}{c}115 / 12 \\
18 \\
86 / 12 \\
12 \\
3 \cdot 9 \\
7 \cdot 3 \\
\text { Normal XX } \\
\text { Mild } \\
10 \\
\text { None detected } \\
\\
6 \rightarrow 20 \\
5 \cdot 7 \rightarrow 9 \cdot 0\end{array}$ \\
\hline
\end{tabular}

suggest Turner's syndrome or Down's syndrome. A moderate amount of dark pubic hair and a small amount of axillary hair were noted. There was no clitoral hypertrophy. The breasts were pendulous but it was difficult to determine the presence of true glandular tissue. Other aspects of the physical examination were within normal limits. Her full scale IQ was 87.

Skeletal maturation was at the 12-year level; skull $x$-ray normal; glucose tolerance test normal, and PBI $6 \mu \mathrm{g} / 100 \mathrm{ml}$. A vaginal smear showed mild oestrogen effect. Chromosome karyotype was normal female.

Sexual development has continued to progress slowly but menarche has not occurred though the child is now $14 \frac{1}{2}$ years of age.

Methods. Growth hormone was determined by double antibody radioimmunoassay, according to the method of Morgan (1966). Urinary 17-OHCS and 17-KS were commercially determined by the standard Porter-Silber colour reaction and the Zimmerman reaction, respectively. Urinary gonadotropins and total oestrogens were also commercially determined, gonadotropins by bioassay and oestrogens by fluorimetry. Skeletal maturation was determined by comparison with the radiological standards for the hand and wrist of Greulich and Pyle (1959). Intelligence testing was performed using the Wechsler Preschool and Primary Scale of Intelligence in Case 1 and the Wechsler Intelligence Scale for Children in Case 2.

\section{Discussion}

The two cases presented have in common with the Prader-Willi syndrome a refractory form of obesity, disordered growth, and intellectual impairment. Though Case 1 has maintained a height just below the 50th centile, she has shown no growth response to her obesity nor has any pubertal growth spurt occurred, though her bone age is 5 years in advance of her chronological age. With her obesity and skeletal maturation taken into consideration, she may be considered to show 
'growth resistance' (Hubble, 1964). Her growth hormone response to arginine was blunted, but this may be attributable to her obesity (Rabinowitz et al., 1967). Case 2, though achieving an IQ in the low normal intelligence range, is functioning significantly below the level of other members of her family. Such mild impairments in growth and intelligence are consistent with the Prader-Willi syndrome (Laurance, 1967; Juul and Dupont, 1967). Case 1 gives a history of the characteristic infantile hypotonia, Case 2 does not.

Delayed sexual development and/or retarded bone age have been characteristics of most cases of the Prader-Willi syndrome reported to date. The precocious development of secondary sexual characteristics in these children seems to be an inconsistent phenomenon, but it may not necessarily disqualify them from this syndrome. It seems that a hypothalamic disturbance is involved in the Prader-Willi syndrome, and might therefore occasionally result in premature activation of gonadotrophin release. The slow progression of sexual development observed in these girls indicates that the process, though initiated early, is imperfect.

Sexual precocity has not previously been related to this type of symptom complex but is not rare in hypothalamic disease. The appearance of both the adrenal and ovarian components of pubertal development suggests primary pituitary activation rather than primary 'end-organ' activity in both organs; though in Case 2, the maturing effect of precocious adrenal activity might have triggered pituitary activation as a secondary phenomenon. One of these children was on thyroid therapy for an extended period, but neither child showed clinical or biochemical evidence of hypothyroidism at any time. Precocious puberty of the 'hormonal overlap' type seen occasionally in hypothyroidism (Van Wyk and Grumbach, 1960) does have to be considered as a possible result of discontinuation of long-term thyroid therapy in Case 1. However, documentation of prompt return of normal endogenous thyroid function makes hormonal overlap an unlikely explanation in this case.

It is reasonable to conclude that the obesity, disordered growth, intellectual defect, and sexual precocity are related to a common central nervous system abnormality and represent a distinct clinical entity. The similarity of this syndrome to the Prader-Willi syndrome in most respects, other than sexual development, suggests that it should be considered a variant of the Prader-Willi syndrome.

\section{REFERENCES}

Cohen, M. M., Jr., and Gorlin, R. J. (1969). The Prader-Willi syndrome. American fournal of Diseases of Children, 117, 213. Dubowitz, V. (1967). A syndrome of benign congenital hypotonia, gross obesity, delayed intellectual development, retarded bone age and unusual facies. Proceedings of the Royal Society of Medicine, 10, 1006.

Greulich, W. W., and Pyle, S. I. (1959). Radiographic Atlas of Skeletal Development of the Hand and Wrist, 2nd ed. Stanford University Press, Stanford, California; Oxford University Press, London.

Hoefnagel, D., Costello, P. J., and Hatoum, K. (1967). PraderWilli syndrome. Fournal of Mental Deficiency Research, 11, 1 .

Hubble, D. (1964). Disorders of growth. In Recent Advances in Paediatrics, p. 190 . Ed. by D. Gairdner. Churchill, London.

Juul, J., and Dupont, A. (1967). Prader-Willi syndrome. Fournal of Mental Deficiency Research, 11, 12.

Laurance, B. M. (1961). Hypotonia, obesity, hypogonadism, and mental retardation in childhood. (Abst.) Archives of Disease in Childhood, 36, 690.

Laurance, B. M. (1967). Hypotonia, mental retardation, obesity, and cryptorchidism associated with dwarfism and diabetes in children. Archives of Disease in Childhood, 42, 126.

Morgan, C. R. (1966). Human growth hormone immunoassay; two-antibody method using I-125 tracer. Proceedings of the Society for Experimental Biology and Medicine, 121, 62.

Prader, A., Labhart, A., and Willi, H. (1956). Ein Syndrom von Adipositas, Kleinwuchs, Kryptorchismus und Oligophrenie nach myatonieartigem Zustand im Neugeborenenalter. Schweizerische Medizinische Wochenschrift, 86, 1260.

Prader, A., and Willi, H. (1963). Das Syndrom von Imbezillităt, Adipositas, Muskelhypotonie, Hypogenitalismus, Hypogonadismus und Diabetes mellitus mit 'Myatonie' Anamnese. In Proceedings of the Second International Congress on Mental Retardation, Vienna 1961; Part I, p. 353 . Ed. by O. Stur. Karger, Basle and New York.

Rabinowitz, D., Merimee, T. J., Nelson, J. K., Schultz, R. B., and Riggs, L. (1967). The hormonal profile in obesity. Transactions of the Association of American Physicians, 80, 190.

Van Wyk, J. J., and Grumbach, M. M. (1960). Syndrome of precocious menstruation and galactorrhea in juvenile hypothyroidism: an example of hormonal overlap in pituitary feedback. fournal of Pediatrics, 57, 416.

Zellweger, H., and Schneider, H. J. (1968). Syndrome of hypotonia-hypomentia-hypogonadism-obesity (HHHO) or PraderWilli Syndrome. American fournal of Diseases of Children, 115, 588.

Correspondence to Dr. D. R. MacMillan, Department of Pediatrics, University of Louisville, School of Medicine, Health Sciences Center, Louisville, Kentucky, 40201, U.S.A. 